\title{
Is Capillary Refill Time an Early Prognostic Factor in COVID-19 Patients?
}

\section{Kapiller Dolum Süresi, COVID-19 Hastalarında Erken Prognostik Faktör mü?}

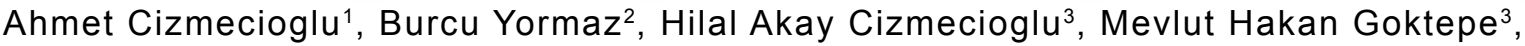 \\ Nijat Ahmadli ${ }^{1}$, Dilek Ergun ${ }^{2}$, Baykal Tulek $^{2}$, Fikret Kanat $^{2}$
}

${ }^{1}$ Selcuk University, Faculty of Medicine, Department of Internal Medicine, Konya, Turkey

${ }^{2}$ Selcuk University, Faculty of Medicine, Department of Chest Diseases, Konya, Turkey

${ }^{3}$ Necmettin Erbakan University, Meram Faculty of Medicine, Department of Internal Medicine, Konya, Turkey

Address correspondence to: Anmet Cizmecioglu, Selcuk University, Faculty of Medicine, Department of Internal Medicine, Konya, Turkey

e-mail: mhakan goktepe@gmail.com

Geliş Tarihi/Received: 4 June 2021 Kabul Tarihi/Accepted: 1 September 2021

\begin{abstract}
Öz
Amaç: Hipoksemi, koronavirüs hastalığında (COVID-19) prognozu belirlemek için kullanılan hayati bir kriterdir. Bu çalışmada, COVID-19 hastalarında hipoksiye bağlı hastalık şiddetini tanımlamada kapiller dolum zamanının (KDZ) etkinliği değerlendirilmiştir.

Hastalar ve Yöntem: Bu prospektif çalışma, COVID-19 hastaları ve yaşça eşleştirilmiş bir sağlıklı grubu ile gerçekleştirilmiştir. Ölçüm için optimum test ortamı sağlandı ve yöntemimizi standartlaştırmak ve ölçümleri (milisaniye cinsinden) kaydetmek için sabit bir akıllı telefon platformu kullanıldı. Kaydedilen videolar daha sonra bir video işleme programı kullanılarak değerlendirildi.

Bulgular: Çalışmaya toplamda 39 COVID-19 hastası ve 40 kontrol grubu katıldı. Hastalar hastalık şiddetlerine göre orta $(n=25)$ veya ağır $(n=14)$ gruplara ayrıldı. Her iki orta / şiddetli grubun ortalama oksijen satürasyonu \%94'ün üzerindeydi. Hastalık şiddetine göre KDZ ölçümleri şiddetli grupta orta gruba göre daha yüksekti $(p=0.009)$. Lenfopeni olmayan hastalarda $(n=18)$, KDZ değerlerinin şiddetli grupta arttığı saptandı $(p=0.008)$. Covid-19'lu hastaların takibinde KDZ kullanımı uygulanabilirdi (AUC: 0.91; $\% 95$ SH 0.848-0.978; $P=0.001)$

Sonuç: Sonuçlarımız, COVID-19'lu hastalarda KDZ süresinin uzayabileceğini göstermektedir. Lenfopenisi olmayan ve $\mathrm{O} 2$ seviyesi normal olan hastalarda, KDZ uzamasının saptanması yoğun bakıma erken kabul için bir kriter olabilir.

Anahtar Kelimeler: Absolüt lenfosit sayısı, COVID-19, hastalık şiddeti, hipoksi, kapiller dolum zamanı

Abstract

Aim: Hypoxemia is a vital criterion used to determine prognosis in coronavirus disease (COVID-19) cases. This study thus examined the effectiveness of capillary refill time (CRT) in defining hypoxiadependent disease severity in COVID-19 patients.

Patients and Methods: This prospective study was conducted with COVID-19 patients and an agematched healthy group. The optimum test ambiance was provided, and a stable smartphone platform was used to record the measurements (in $\mathrm{ms}$ ) to standardize our method. The captured videos were then evaluated using a video processing program.

Results: In total, 39 patients with COVID-19 and 40 control groups participated in this study. The patients were further divided into the moderate $(n=25)$ or severe group $(n=14)$ according to disease severity. The mean oxygen saturation of both moderate/severe groups was above $94 \%$. Per disease severity, the CRT measurements were higher in the severe group than in the moderate group $(p=0.009)$. In patients without lymphopenia $(n=18)$, CRT values were found to be increased in the severe group $(p=0.008)$. The use of CRT in patients with Covid-19 was practicable (AUC: $0.91 ; 95 \% \mathrm{Cl} 0.848-0.978 ; \mathrm{P}=0.001$ ). Conclusions: Our results show that CRT prolongation can occur in patients with COVID-19. In patients without lymphopenia and with normal $\mathrm{O} 2$ levels, detecting CRT prolongation may be a criterion for early admission to ICU.
\end{abstract}

Key words: Absolute lymphocyte count, COVID-19, disease severity, hypoxemia, capillary refill time
Cite this article as: Cizmecioglu A, Yormaz B, Akay Cizmecioglu H, Goktepe MH, Ahmadli N, Ergun D, Tulek B, Kanat F. Is Capillary Refill Time an Early Prognostic Factor in COVID-19 Patients? Selcuk Med J 2021;37(3): 224-230
Disclosure: None of the authors has a financial interest in any of the products, devices, or drugs mentioned in this article. The research was not sponsored by an outside organization. All authors have agreed to allow full access to the primary data and to allow the journal to review the data if requested. 


\section{INTRODUCTION}

The COVID-19 outbreak is a pandemic disease in which we frequently see different presentations and complications. Although the disease seems to mostly affect the respiratory tract, it has caused fibrosis in various organs $(1,2)$. COVID-19 has a high mortality rate of up to $12 \%$ (3). As cases continue to be reviewed, essential parameters in COVID19's prognosis (dyspnea, tachypnea, sPO2 level, comorbidity, immunosuppressive therapy, laboratory abnormalities) must be further determined. Patients with severe COVID-19 disease complain about dyspnea according to the degree of pulmonary involvement. Hypoxemia caused by dyspnea will affect the peripheral tissues of the human body. Many tools can measure peripheral blood supply and oxygenation. Capillary refill time (CRT) can also be included in this class as a practical, non-invasive, reliable, and inexpensive physical examination performed at the bedside.

CRT effectively evaluates the peripheral vascular bed's fullness in favorable conditions, especially in the intensive care unit (ICU) (4). Fundamentally, it is the observation of the filling rate of the arteriole and capillary system. CRT can give accurate objective information in case of septic shock (5). In addition, it can quickly and safely show severe dehydration in pediatric patients $(6,7)$. CRT's examination time of < $2 s$ is considered one means of proving circulatory disorder $(8,9)$. However, though CRT is considered such an important method, it is influenced by many factors, such as age, ambient or skin temperature, ambient light, pressure application, and observer reliability; therefore, CRT is not a daily measurement tool $(4,10)$.

The year 2020 has been a period in which medicine must make several evaluations regarding COVID-19. A test such as CRT, which can predict multiple organ failure (MOF) and evaluate tissue perfusion, has not yet been applied in patients with COVID-19. The evaluations and results of our study thus contribute to determining CRT's role in COVID-19 prognosis.

\section{PATIENTS AND METHODS}

Our research consisted of a prospective study conducted with patients diagnosed with COVID-19 via polymerase chain reaction (PCR) and computed tomography (CT), and an age-matched control group. APCR test was definitely requested from patients with a CT diagnosis (Figure 1). Study approval numbered 2020/296 was obtained from the university ethics
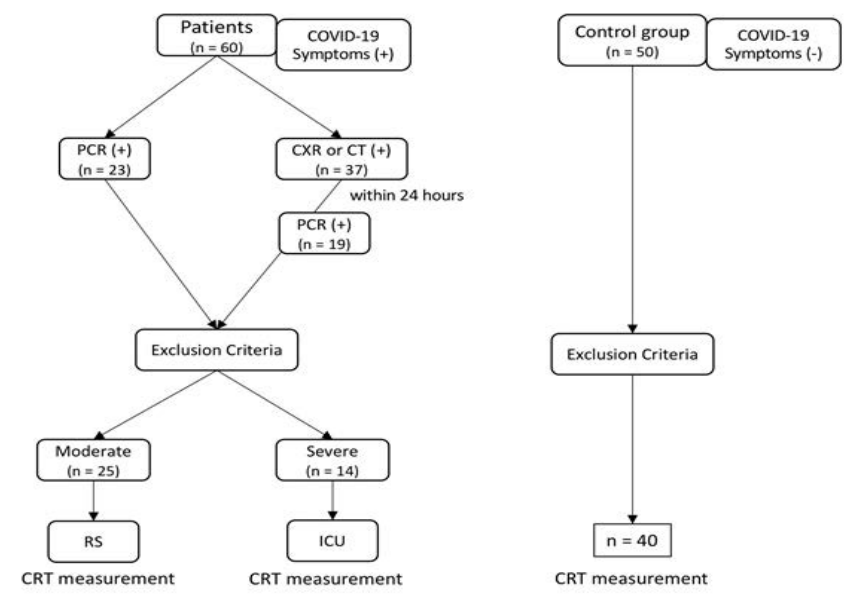

PCR, Polymerase Chain Reaction; CT, Computed tomography; CXR, Chest X-ray; RS, Respiratory Service; CRT, Capillary refill time; ICU, Intensive care unit

Figure 1. Study design

committee. Informed consent forms were received from all participating patients prior to the study. The patients' laboratory parameters were recorded simultaneously. Those over 18 years of age who did not have decongestant, caffeine, or tea intake within the preceding $24 \mathrm{~h}$ were included in the study, while those with nail bed pathology (onychomycosis, cosmetic application, manicure) were excluded. Then, the patients were categorized into two groups based on COVID-19 disease severity (11). Accordingly, patients with clinical complaints (fever, cough, anosmia, headache, sour throat), pneumonic infiltrations in Chest X-Ray (CXR) or CT, and an $\mathrm{O}_{2}$ saturation $>94 \%$ were rated as moderate; and those with serious clinics (tachypnea and $\mathrm{O}_{2}$ saturation < $94 \%$ ) and bilateral CXR or CT pneumonic infiltrations were rated as severe (11). Cases with absolute lymphocyte count < 1000 x106/L were considered lymphopenic (12). The control group consisted of age-matched healty individuals who had no disease symptoms and had no comorbities.

We began taking measurements after obtaining optimum CRT conditions. Firstly, body temperature measurements were taken from all patients before evaluation, and between 36.5 - 38 Celcius was considered normal (13). Secondly, age-matching was provided in the control group for the CRT-caused age deflection effect. Thirdly, in order not to be affected by the light, the measurement was made at the same time of the day (between 09-10 am), and 
the amount of light of the measurement area has been set for a brightness level to 300-500 lux, via a photometric freeware software (Lux-Meter) installed on the smartphone used in the measurement. Finally, measurements were made by the same healthcare personnel to prevent measurement technique variations.

To standardize each evaluation, we designed a 3D platform via Solidworks 2019 (Dassault Systèmes $\mathrm{HQ}$ ) and a manufacturing procedure with Ultimaker Cura (ver. 4.6.2). Images were recorded with a smartphone placed on a mobile, focused tray that can observe the finger placement area from above. After the patient's finger was placed in the appropriate position, adequate pressure was applied to the finger pulp or nail root with a transparent, flat, and hardened tool until whitening occurred, and the examination was completed by immediately pulling the tool from the camera frame after $5 \mathrm{~s}$. The pressure applied was documented by a physical open code programming platform (Arduino). Accordingly, the minimum pressure required for the evaluation was 4 Newtons. All these stages were recorded in video format via the smartphone placed on the tray platform. The images taken were evaluated using the color threshold filter available through VLC media player (ver. 3.0.5, Vetinari clang-902.0.39.2) software to show the visual blood flow in the images. We then made evaluations by observing the images from the moment the blood flow disappeared until the refill began and the skin color completely regulated. The time between these moments was recorded on the screen in $\mathrm{ms}$.

\section{Statistical Analysis}

Statistical analyses were performed using SPSS ver. 21 (SPSS Inc., Chicago, IL, USA). We used a Pearson correlation to correlate normally distributed data, whereas in non-normal data, we used a Spearman correlation. We also used independent t-tests to compare the CRT results between the COVID-19 patients and control group. In continuous data pinpointing comparisons with CRT and in comparisons according to disease severity, an independent t-test was used in normal distributions and the Mann-Whitney U-test in non-normal distributions. The area under the receiver-operating characteristics curve (AUC) and 95\% confidence intervals $(\mathrm{Cl})$ were used to assess the ability of each CRT of the patient and control groups to predict the severity. In all calculations, a p-value of 0.05 was accepted as significant.

\section{RESULTS}

Thirty-nine patients with COVID-19 diagnosed via PCR and 40 age-matched healthy control group were included in this study. The male and female populations were $69 \%: 31 \%$ in the patient group and $50 \%: 50 \%$ in the control group $(p=0.110)$. The mean age of the patients and control group was $70.4 \pm 13.7$ and $69.3 \pm 13$, respectively $(p=0.124)$. In the patient group, $51.3 \%$ of the patients with positive CT had a positive PCR, and the overall PCR positivity rate was $65 \%$. Among the patients grouped according to disease severity, the moderate patients ( $n=25$, $64 \%$ ) were followed up in the respiratory service (RS), and severe ones $(n=14,36 \%)$ were treated at ICU. During treatment, none of the patients from moderate and severe groups were transferred to each other.

There were no vital abnormalities such as fever, pulse irregularity, low saturation, tachypnea in the control group. In the control group, mean body temperature was $36.8 \pm 0.6$, mean saturation percentage was $96 \pm 2$, and mean heart rate was $77.1 \pm 17.2$. In the vital evaluations of the patient group, we did not note high-fever and dyspnea in any of the patients in the moderate group. Two of the patients had a non-persistent tachycardic period, one of them used montelukast for asthma treatment which needs no further medications, and the mean oxygen saturation percentage was $95.56 \pm 1.3$ in the moderate patient group. Similarly, 2 of the patients had asthma in the severe group, but their oxygen saturations were above $90 \%$. The severe group had no high-fever and tachycardia, unlike low oxygen saturation percentage (mean 92.85 \pm 1.3 ) and moderate dyspnea were noted. The demographic data and laboratory values of the patients are given below in Table 1.

CRT was measured above normal in 29 patients $(74.3 \%)$ in the patient group. The longest CRT was $6.568 \mathrm{~s}$, and it was in the patient group. The mean CRT for the patients with COVID-19 was prolonged (3.18 \pm 1.57$)$, whereas, in the control group, the mean CRT was at normal range $(1.32 \pm 0.4 \mathrm{~s})$. The CRT results comparison between the patient and control groups was statistically significant as well $(p=0.001, \pm=$ 0.404) (Figure 2/a). Age was positively correlated with CRT values in both patient $(r=0.248)$ and control group ( $r=0.302)$. While the patient CRT values positively correlated with C-Reactive Protein (CRP) $(r=0.503)$ and International Normalized Ratio (INR) $(r=0.479)$, conversely, they negatively correlated with $\mathrm{PO}_{2}(\mathrm{r}=-0.339)$, and platelet count $(\mathrm{r}=-0.349)$. In addition, there was a statistical significance between 
Table 1. Demographics and Laboratory findings of patients with COVID-19

\begin{tabular}{|c|c|c|c|c|}
\hline & $\begin{array}{l}\text { All Patients } \\
(n=39)\end{array}$ & $\begin{array}{l}\text { Respiratory Service } \\
(n=25)\end{array}$ & $\begin{array}{l}I C U \\
(n=14)\end{array}$ & P value \\
\hline \multicolumn{5}{|l|}{ Characteristics } \\
\hline Males, n (\%) & $25(64.1 \%)$ & $12(48 \%)$ & $13(92 \%)$ & 0.005 \\
\hline Age & $64.4 \pm 16.3$ & $66.3 \pm 17.2$ & $75 \pm 13.2$ & 0.112 \\
\hline \multicolumn{5}{|l|}{ Comorbidities } \\
\hline $\mathrm{DM}$ & $12(30.8 \%)$ & $7(28 \%)$ & $5(35.7 \%)$ & 0.616 \\
\hline $\mathrm{HT}$ & $18(46.2 \%)$ & $9(36 \%)$ & $9(64.3 \%)$ & 0.089 \\
\hline CAD & $7(17.9 \%)$ & $5(20 \%)$ & $2(14.3 \%)$ & 0.655 \\
\hline COPD orland Asthma & $3(7.7 \%)$ & $1(4 \%)$ & $2(14.3 \%)$ & 0.247 \\
\hline WBC, $\times 10 \% / L$ & $7.8(4.8-10.9)$ & $7.3(4.7-10)$ & $9.5(6.2-12.9)$ & 0.228 \\
\hline ANC, $\times 10^{9} / \mathrm{L}$ & $5.3(3.1-8.8)$ & $4.1(3.1-6.8)$ & $7.8(3.5-11.1)$ & 0.149 \\
\hline $\mathrm{ALC}, \times 10^{9} / \mathrm{L}$ & $0.9(0.7-1.66)$ & $1.2(0.6-2.2)$ & $0.9(0.7-1)$ & 0.251 \\
\hline $\mathrm{N} / \mathrm{L} \mathrm{r}$ & $4.83(2.67-8.71)$ & $3.39(2.59-5.61)$ & $7.73(5.1-14.45)$ & 0.026 \\
\hline AMC, $\times 10^{9} / \mathrm{L}$ & $0.7(0.5-0.9)$ & $0.7(0.5-0.9)$ & $0.7(0.4-0.9)$ & 0.874 \\
\hline $\mathrm{Hb}, \mathrm{gr} / \mathrm{dL}$ & $11.78 \pm 2.18$ & $11.94 \pm 2.44$ & $11.52 \pm 1.67$ & 0.573 \\
\hline PIt count, $\times 10^{9} / \mathrm{L}$ & $180(159-276)$ & $202(163-301)$ & $164.5(137-191)$ & 0.087 \\
\hline $\mathrm{CRP}, \mathrm{mg} / \mathrm{L}$ & $21.8(6.5-69.5)$ & $9.9(4.5-23.5)$ & $74.9(41.7-104.1)$ & 0.001 \\
\hline Procalcitonin, $\mu \mathrm{g} / \mathrm{L}$ & $0.07(0.05-0.16)$ & $0.06(0.05-0.1)$ & $0.12(0.06-0.44)$ & 0.017 \\
\hline Ferritine, $\mathrm{ng} / \mathrm{mL}$ & $227(102.7-418.8)$ & $151.2(76-408)$ & $284(213-502)$ & 0.044 \\
\hline D-Dimer, ng/mL & $661(470-1120)$ & 661 (411-1105) & $773(571-1892)$ & 0.460 \\
\hline INR & $1.04(1-1.1)$ & $1.02(1-1.1)$ & $1.05(1-29.8)$ & 0.017 \\
\hline APTT, sec & $21.62 \pm 11.1$ & $23.05 \pm 7.9$ & $19.05 \pm 15.2$ & 0.373 \\
\hline $\mathrm{pH}-\log \left[\mathrm{H}^{+}\right]$ & $7.37 \pm 0.05$ & $7.37 \pm 0.05$ & $7.37 \pm 0.06$ & 0.802 \\
\hline $\mathrm{PCO}_{2},(\%)$ & $45.71 \pm 10.26$ & $47.41 \pm 12.26$ & $42.66 \pm 3.87$ & 0.084 \\
\hline Met $\mathrm{Hb},(\%)$ & $0.5(0.2-1)$ & $0.7(0.35-0.95)$ & $0.35(0.2-1.1)$ & 0.331 \\
\hline Lactat $(\%)$ & $2.5(1.7-3.8)$ & $2(1.7-3)$ & $2.85(1.6-5)$ & 0.361 \\
\hline $\begin{array}{l}\mathrm{HCO}_{3}^{-1},(\%) \\
\mathrm{SPO}_{2},(\%)\end{array}$ & $25.1(22.2-27.4)$ & $25.6(23.1-28.1)$ & $23.8(21.8-26.3)$ & 0.361 \\
\hline Hypoxemia & $94.58 \pm 1.87$ & $95.56 \pm 1.35$ & $92.85 \pm 1.35$ & 0.001 \\
\hline$\left(\mathrm{sPO}_{2}<94 \%\right), \mathrm{n}(\%)$ & $17(44 \%)$ & $4(16 \%)$ & $13(93 \%)$ & 0.477 \\
\hline $\begin{array}{l}\text { Lymphopenia at } \\
\mathrm{sPO}_{2}<94 \%, \text { n (\%) }\end{array}$ & $10(59 \%))$ & $2(8 \%)$ & $8(57 \%)$ & 0.044 \\
\hline CRT, sec & $3.18 \pm 1.57$ & $2.71 \pm 1.45$ & $4.01 \pm 1.47$ & 0.011 \\
\hline
\end{tabular}

$\mathrm{P}$ values are the comparison of severe and moderate groups. (Chi-square test, Mann-Whitney $U$ test, or Independent Samples t-test); Data are the median, $\mathrm{n}(\%)$, or $\mathrm{n} / \mathrm{N}(\%)$; ALC, absolute lymphocyte count; ANC, absolute neutrophil count; AMC, absolute monocyte count; CAD, coronary artery disease; COPD, chronic obstructive pulmonary disease; CRP, C-reactive protein; CRT, capillary refill time; DM, Diabetes Mellitus; Hb, Hemoglobin; HT, Hypertension; INR, international normalized ratio; N/L r: Neutrophil-lymphocyte ratio; PIt, Platelet; PTT, partial thromboplastin time; sPO2, blood oxygen saturation; WBC, White blood cell.

prolonged CRT measurements and PO2 $(p=0.018$, $\eta=0.143)$, and $D$-dimer values $(p=0.016, \eta=0.149)$. However, there was no statistical relation between CRT and Complete Blood Count abnormalities such as anemia, lymphopenia, monocytopenia, infection indicators (CRP, procalcitonin, ferritin), and local acidemia influencers such as lactate, bicarbonate, $\mathrm{PCO}_{2}, \mathrm{pH}(\mathrm{p}>0.05)$. In addition, no correlation or statistical significance was found between chronic diseases in the study and CRT measurements.

In comparing the moderate and severe groups in terms of CRT, as shown in figure $2 / b$, a MannWhitney $U$ test revealed a significant difference $(p=$ $0.009, n=0.175)$. We also noted another significance between the patient groups in terms of gender, CRP, procalcitonin, ferritin, and blood oxygen saturation $(p<0.05)$. The percentage of lymphopenia $(<1000$ $x 106$ per $L$ ) in the moderate patient group with a normal oxygen saturation $\left(\mathrm{sPO}_{2} \geq 94 \%\right)$ was $44 \%(n=11)$. Prolonged CRT $(3.85 \pm 1.39 \mathrm{~s})$ was measured in $63.6 \%(n=7)$ of these lymphopenic, non-hypoxic patients in the moderate group. Similarly, lymphopenia was detected in $80 \%(n=8)$ of the severe patients with an oxygen saturation $<94 \%$. The mean CRT was prolonged (3.48 $\pm 1.14 \mathrm{~s})$ in $90 \%$ $(n=9)$ of lymphopenic severe patients. However, in patients without lymphopenia there was a difference between the groups' CRT results in terms of treatment location ( $p=0.008$ ) (Figure $2 / c)$. And the neutrophil to lymphocyte ratio results were statistically significant 

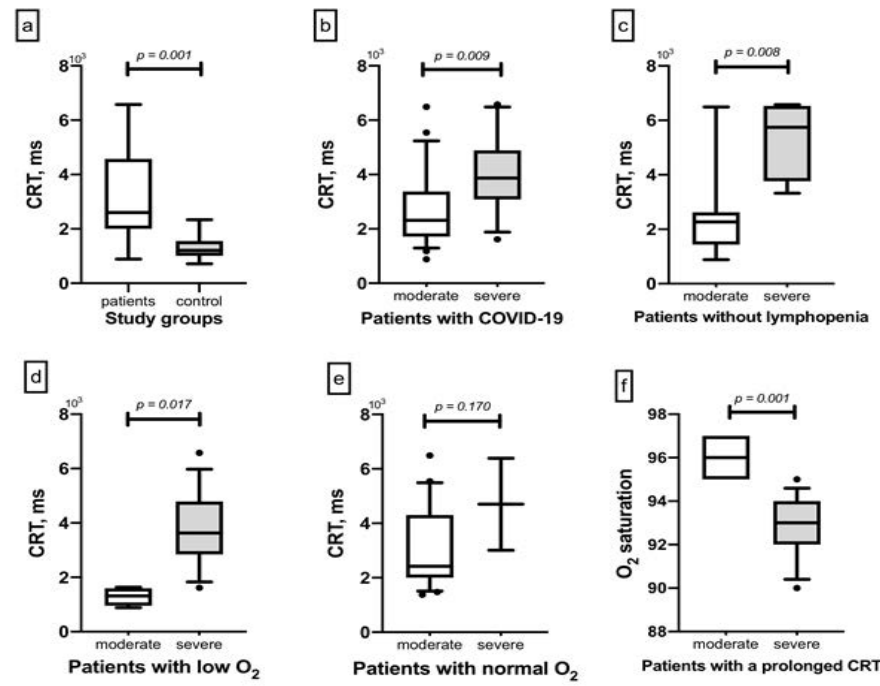

Figure 2. a) CRT comparison between patients and control group; b) CRT comparison among the patient subgroups; c) CRT comparison among the patient subgroups without lymphopenia; d) CRT comparison among the patient subgroups at low $\mathrm{O}_{2}$ saturation; e) CRT comparison among the patient subgroups at normal $\mathrm{O}_{2}$ saturation; f) Saturation comparison among the patient subgroups with prolonged CRT; CRT, Capillary refill time (ms).

in the severe group $(p=0.026)$.

When CRT measurements were evaluated according to the patients' saturations, there was a difference between the moderate and the severe groups at low saturations $(p=0.002, \eta=0.50)$ (Figure 2/d), whereas a Mann-Whitney U-test showed that the inter-groups CRT differences were not statistically significant at normal saturations $(p=0.182)$ (Figure 2/e). A similar CRT differences were not detected in other prognostic markers such as CRP, lactate, d-dimer, procalcitonin, and ferritin. And finally, we found a statistically significant difference in the $\mathrm{O}_{2}$ saturation comparison of 29 patients with prolonged CRT results $(p=0.001)$ (Figure $2 / f)$. The evaluation for the prognostic significance of CRT measurement was given in figure 3 (AUC: $0.91 ; 95 \% \mathrm{Cl} 0.848-0.978$; S.E.: 0.03; $P=0.001)$.

\section{DISCUSSION}

Our study evaluated the CRT in COVID-19 cases. There was an increase in CRT for the patients with COVID-19 compared to the control group. CRT prolongation was also more frequent among the ICU

\section{CRT ROC curve}

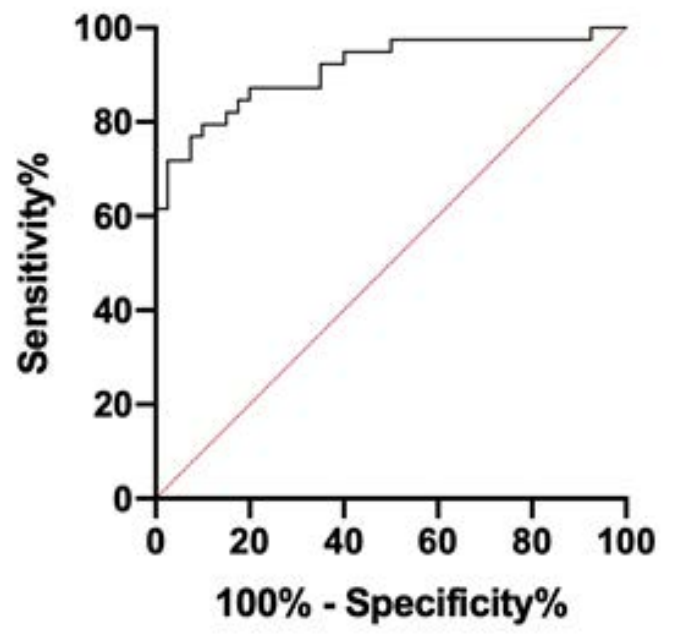

Figure 3. The ROC analysis of the CRT results.

patients than the RS patients. In lymphopenic patients, the mean ICU CRT values were greater than the RS CRT values. And, all patients with normal oxygen saturation were a tendency to have a prolonged CRT. There are many CRT studies that predict sepsis per sepsis criteria. These studies have generally been carried out in critical locations, such as ICUs and emergency services. A recent research found CRT to correlate with lactate levels in the ICU (14). Similarly, when the patient lactate level was $>2 \mathrm{mmol}$, CRT prolongations noted significant regardless of oxygen saturation (15). Although other reasons may have increased lactate levels in these studies, the results were found to be associated with CRT. Likewise, lactate is also among COVID-19's prognostic factors. We took our study's lactate samples from the arterial blood gas test. The mean lactate levels were $2.7 \pm 1.5$ in the moderate group and $3.23 \pm 1.6$ in the severe group. There was no correlation between CRT and lactate levels, however, when the lactate level $>2$ $\mathrm{mmol}$, we found a relationship in CRT results between the RS and ICU patients.

In a study investigating the impact of cold conditions on CRT, periodic measurements were taken from the central and peripheral regions of the human body (10). A similar study stated that the different results are more pronounced in shock cases (4). In our study, 14 of the patients were monitored in the ICU. Additionally, fever confirmations were performed from the forehead in both the RS and ICU. 
Hypothermic measurements were not available in any of the patients. Nevertheless, we expected the CRT measurements in the ICU to be prolonged. In our study, the local factors affecting the CRT did not differ statistically from the CRT results, thus, this indicates that the CRT measurements were made under optimal conditions. Due to physiological aging, CRT also changes with age. Anderson et al. studied CRT's environmental factors with 1,000 participants, finding an increase of $3.3 \%$ in CRT per each decade of life (16). Another issue evaluated in the study was ambient temperature. The researchers found that CRT was affected more by patient temperature than ambient temperature. Therefore, they still considered CRT to be clinically significant. The minimum age in our study was fourty-eight, however we matched ages in the control group in order to minimize the agedependent CRT prolongation impact. Consequently, age was positively correlated with CRT values in both patient and control group. None of the patients had a recorded high or low temperature. Although we compared the temperature values of the two different conditions, the CRT change level was trivial since no personal fever elevations occurred. In this way, our CRT measurements were affected by external factors as little as possible. In the evaluation of chronic diseases, we did not find any statistical difference between the two patient groups.

When we evaluated other laboratory results that may affect CRT, such as age, we found that CRT was highly positively correlated with CRP and moderately positively correlated with INR. Conversely, it was moderately negatively correlated with sPO2 level and platelet count. Thus, both negative and positive correlations seem to be compatible with physiopathology and the clinical stage. CRT will be prolonged because the increase in the platelet count will decrease blood fluidity, inflammation will cause tissue hypoxia, and hypoxia will increase arteriole constriction (17). Violi et al. (18) (2020) further examined hypercoagulation and antithrombotic therapy in patients with COVID-19. They found that pneumonia, coagulation disorders, platelet activation, and artery dysfunction can lead to MOF. CRT, which can rapidly evaluate peripheral circulation in the process leading to MOF after macrophage activation syndrome (MAS), can prove useful in this regard. None of our patients progressed toward MOF or MAS. However, CRT was significant in evaluating microcirculation of ICU patients as these patients are more prone to MAS. In our study, CRT prolongation was higher in patients without lymphopenia in ICU compared to the service. Detection of CRT prolongation in patients without lymphopenia may predict the predisposition to MAS before lymphopenia occurs.

In a study evaluating subjective CRT measurements, 12 experts commented on 34 different CRT videos (19). There were even $9 \mathrm{~s}$ among the results with a median value of 1.5 . In a similar study, the CRT measurements of 63 healthy people were taken by direct view or video analysis methods (20). In the study with two different observers, a time difference of at least $1 \mathrm{~s}$ was detected in the results. Due to this observer-induced problem, only one person evaluated the video recordings in our study. Furthermore, the videos were interpreted with a video processing program that showed the pulp's blood flow from the pulp turning white with pressure to complete restoration. Since the results were recorded in $\mathrm{ms}$, the error level, if any, was $1 / 1000$. Finally, we found that CRT measurements increased in patients with normal saturation but lymphopenia. This may be clinically important because prolonging CRT before low $\mathrm{O} 2$ saturation happens may mean predicting peripheral circulatory disorders in COVID-19. This study's scope was limited in terms of evaluating the videos with the human eye instead of a digital software. The small sample size did not allow us to use machine-learning software either.

In conclusion, this study evaluated the CRT measurements in patients with COVID-19. This study's findings may provide new prognostic value in the disease's survey. Our study also revealed that CRT was more prolonged in the COVID-19 group: as COVID-19's severity increases, so does CRT. Moreover, in patients without lymphopenia, CRT prolongation may more valuable for the prognosis. Further studies need to be carried out to develop new prognosis strategies for COVID-19.

Conflict of interest: Authors declare that there is no conflict of interest between the authors of the article.

Financial conflict of interest: Authors declare that they did not receive any financial support in this study.

Address correspondence to: Ahmet Cizmecioglu, Selcuk University, Faculty of Medicine, Department of Internal Medicine, Konya, Turkey

e-mail: mdahmet2002@gmail.com

Mobile Phone Number: +90 5053568399 


\section{REFERENCES}

1. Smyk W, Janik MK, Portincasa P, et al. COVID-19: Focus on the lungs but do not forget the gastrointestinal tract. Eur $\mathrm{J}$ Clin Invest 2020;50(9):e13276.

2. Sardu C, Gambardella J, Morelli MB, et al. Hypertension, thrombosis, kidney failure, and diabetes: Is COVID-19 an endothelial disease? A comprehensive evaluation of clinical and basic evidence. J Clin Med 2020;9(1417):1-22.

3. Di Stadio A, Ricci G, Greco A, et al. Mortality rate and gender differences in COVID-19 patients dying in Italy: A comparison with other countries. Eur Rev Med Pharmacol Sci 2020;24(8):4066-7.

4. Pickard A, Karlen W, Ansermino JM. Capillary refill time: Is it still a useful clinical sign? Anesth Analg 2011;113(1):120-3.

5. Ait Oufella H, Bige N, Boelle PY, et al. Capillary refill time exploration during septic shock; Intensive Care Med 2014;40(7):958-64.

6. Shavit I, Brant R, Nijssen Jordan C, et al. A novel imaging technique to measure capillary-refill time: Improving diagnostic accuracy for dehydration in young children with gastroenteritis. Pediatrics 2006;118(6):2402-8.

7. Popov T. Review: Capillary refill time, abnormal skin turgor, and abnormal respiratory pattern are useful signs for detecting dehydration in children. Evid Based Nurs 2005;8(2):57.

8. Şen S, Eti Aslan F. The factors effecting capillary refill time. Çağdaş Tıp Dergisi 2015;5(1-Ek):100-98.

9. King D, Morton R, Bevan C. How to use capillary refill time. Arch Dis Child Educ Pract Ed 2014;99(3):111-6.

10. John RT, Henricson J, Junker J, et al. A cool response-the influence of ambient temperature on capillary refill time. $J$ Biophotonics 2018;11(6):e201700371.

11. COVID-19 treatment guidelines. https://www. covid19treatmentguidelines.nih.gov/overview/managementof-covid-19/ (Accessed on 9/17/2020).
12. Aproach to the adult with lymphocytosis or lymphocytopenia. https://www.uptodate.com/contents/approach-to-the-adultwith-lymphocytosis-or-lymphocytopenia/ (Accessed on 9/17/2020).

13. O'Grady NP, Barie PS, Bartlett JG, et al. Guidelines for evaluation of new fever in critically ill adult patients: 2008 update from the American College of Critical Care Medicine and the Infectious Diseases Society of America. Crit Care Med 2018;36(4):1330-49.

14. Morimura N, Takahashi K, Doi $\mathrm{T}$, et al. A pilot study of quantitative capillary refill time to identify high blood lactate levels in critically ill patients. Emerg Med J 2015;32(6):444-8.

15. Oi $Y$, Sato K, Nogaki A, et al. Association between venous blood lactate levels and differences in quantitative capillary refill time. Acute Med Surg 2018;5(4):321-8.

16. Anderson B, Kelly AM, Kerr D, et al. Impact of patient and environmental factors on capillary refill time in adults. Am J Emerg Med 2008;26(1):62-5.

17. Hinshaw LB. Sepsis/septic shock: Participation of the microcirculation: An abbreviated review. Crit Care Med 1996;24(6):1072-8.

18. Violi F, Pastori D, Cangemi $R$, et al. Hypercoagulation and antithrombotic treatment in coronavirus 2019: A new challenge. Thromb Haemost 2020;120(6):949-56.

19. Sheridan DC, Baker SD, Kayser SA, et al. Variability of capillary refill time among physician measurements. J Emerg Med 2017; 53(5):e51-e7.

20. Espinoza ED, Welsh S, Dubin A. Lack of agreement between different observers and methods in the measurement of capillary refill time in healthy volunteers: An observational study; Rev Bras Ter Intensiva 2014;26(3):269-76. 